\title{
Allicin inhibits oxidative stress-induced mitochondrial dysfunction and apoptosis by promoting PI3K/AKT and CREB/ERK signaling in osteoblast cells
}

\author{
GUOLIANG DING, JIANQUAN ZHAO and DIANMING JIANG \\ Department of Orthopedics, First Affiliated Hospital of Chongqing Medical University, \\ Chongqing 400016, P.R. China
}

Received June 22, 2015; Accepted March 3, 2016

DOI: $10.3892 /$ etm.2016.3179

\begin{abstract}
Osteoporosis is a disease of the skeleton that is characterized by the loss of bone mass and degeneration of bone microstructure, resulting in an increased risk of fracture. Oxidative stress, which is known to promote oxidative damage to mitochondrial function and also cell apoptosis, has been recently indicated to be implicated in osteoporosis. However, there are few agents that counteract oxidative stress in osteoporosis. In the present study, the protective effects of allicin against the oxidative stress-induced mitochondrial dysfunction and apoptosis were investigated in murine osteoblast-like MC3T3-E1 cells. The results demonstrated that allicin counteracted the reduction of cell viability and induction of apoptosis caused by hydrogen peroxide $\left(\mathrm{H}_{2} \mathrm{O}_{2}\right)$ exposure. The inhibition of apoptosis by allicin was confirmed by the inhibition of $\mathrm{H}_{2} \mathrm{O}_{2}$-induced cytochrome $c$ release and caspase-3 activation. Moreover, the inhibition of apoptosis by allicin was identified to be associated with the counteraction of $\mathrm{H}_{2} \mathrm{O}_{2}$-induced mitochondrial dysfunction. In addition, allicin was demonstrated to be able to significantly ameliorate the repressed phosphoinositide 3-kinase (PI3K)/AKT and cyclic adenosine monophosphate response element-binding protein (CREB)/extracellular-signal-regulated kinase (ERK) signaling pathways by $\mathrm{H}_{2} \mathrm{O}_{2}$, which may also be associated with the anti-oxidative stress effects of allicin. In conclusion, allicin protects osteoblasts from $\mathrm{H}_{2} \mathrm{O}_{2}$-induced oxidative stress and apoptosis in MC3T3-E1 cells by improving mitochondrial function and the activation of PI3K/AKT and CREB/ERK
\end{abstract}

Correspondence to: Dr Dianming Jiang, Department of Orthopedics, First Affiliated Hospital of Chongqing Medical University, 1 Friendship Road, Yuzhong, Chongqing 400016, P.R. China

E-mail:dianm_jiang@126.com

Key words: allicin, oxidative stress, MC3T3-E1 cells, mitochondrial dysfunction, PI3K/AKT, CREB/ERK signaling. The present study implies a promising role of allicin in oxidative stress-associated osteoporosis.

\section{Introduction}

Osteoporosis is a skeletal disease characterized by the loss of bone mass and degeneration of bone microstructure, which results in an increased risk of fracture $(1,2)$. Various physiological or pathological factors, such as menopause, age, sustained glucocorticoid therapy and endocrine disorders, contribute to osteoporosis (2-4). Over half of women aged $>50$ years old will suffer from osteoporosis or osteoporotic fracture during their lifetime (5). Previous evidence has demonstrated that food intake and glucose metabolism are directly linked to bone remodeling (6), and they act via regulating the systemic release of the osteoblast-specific protein osteocalcin (7). This link is also suggested by the close association between obesity, osteoporosis and diabetes $(8,9)$. However, the pathogenesis of osteoporosis requires clarification.

Oxidative stress (OS) has been recognized to serve a role in the pathogenesis of various diseases, including cerebrovascular disorders (10), diabetes mellitus (11) and cardiovascular disease $(12,13)$. Studies have indicated that the formation and reabsorption of dynamic bone tissue are also affected by OS and/or antioxidant enzyme deficiency (14-17). OS is a biochemical disequilibrium promoted by excessive production of free radicals and reactive oxygen species (ROS), including hydrogen peroxide $\left(\mathrm{H}_{2} \mathrm{O}_{2}\right)$ and the superoxide anion $\left(\mathrm{O}_{2}{ }^{-}\right)$, which are produced from an endogenous oxidative metabolism, including the mitochondria, peroxisomes and inflammatory cell activation (18), in addition to exogenous sources. Excessive ROS are a major cause of cellular damage and death in a variety of pathological conditions $(19,20)$, acting by regulating the processes involved in the mitochondrial dysfunction and the promotion of apoptosis. An increased generation of ROS induces cytochrome $c$ release from mitochondria (21) and promotes apoptosis (22). However, the role of ROS-induced mitochondrial dysfunction and apoptosis in osteoporosis remains unclear.

Multiple natural products and drugs with antioxidant properties have been investigated for their therapeutic use 
and prevention of OS injury. In particular, proanthocyanidins from grape seeds inhibit $\mathrm{H}_{2} \mathrm{O}_{2}$-induced apoptosis in MC3T3-E1 cells by ameliorating mitochondrial dysfunction (23). The present study used allicin, a natural ingredient that is derived from garlic (24). Allicin was reported to exert multiple biological antimicrobial, immune-modulatory and anti-cancer effects (25). Furthermore, allicin also exerts antioxidant effects at the physiological level (25), particularly against OS in cardiovascular diseases that are closely associated with oxidative stress $(26,27)$. Recently, it was indicated to regulate the pro-inflammatory cytokines in postmenopausal osteoporotic women (28), implying a possible and bright prospect for an osteoporosis treatment.

The present study investigated the protective effects of allicin against $\mathrm{H}_{2} \mathrm{O}_{2}$-induced mitochondrial dysfunction and apoptosis in the osteoblast-like MC3T3-E1 cells, which are commonly used to study osteogenic development.

\section{Materials and methods}

Reagents, cell culture and treatment. Allicin (98\% purity; Shaanxi Ciyuan Biotech Co.,Ltd., Xi'an, China) was dissolved in deionized water. The same batch of allicin was used for all of the experiments. Minimum essential medium (MEM)- $\alpha$ and fetal bovine serum (FBS) were purchased from Gibco (Thermo Fisher Scientific, Inc., Waltham, MA, USA). $\mathrm{H}_{2} \mathrm{O}_{2}$ was purchased from Sigma-Aldrich (St. Louis, MO, USA). Murine osteoblastic MC3T3-E1 cells were purchased from American Type Culture Collection (Manassas, VA, USA) and cultured at $37^{\circ} \mathrm{C}$ under $5 \% \mathrm{CO}_{2}$ in MEM- $\alpha$ supplemented with $10 \%$ FBS (or $2 \%$ FBS for cell maintenance) and $1 \%$ penicillin/streptomycin (CSPC Pharmaceutical Group Limited, Shijiazhuang, China). The cells were treated with $200 \mu \mathrm{M}$ $\mathrm{H}_{2} \mathrm{O}_{2}$ for $6 \mathrm{~h}$ in order to induce OS, and allicin treatment was performed with a concentration of 10,30 or $100 \mu \mathrm{g} / \mathrm{ml}$ for $24 \mathrm{~h}$.

Cell viability and apoptosis assay. The viabilities of the MC3T3-E1 cells were evaluated by MTT assay, subsequent to the various treatments. Briefly, MC3T3-E1 cells were seeded in 96-well plates, cultured to $\sim 85 \%$ confluence and were then treated with $200 \mu \mathrm{M} \mathrm{H}_{2} \mathrm{O}_{2}$ for $6 \mathrm{~h}$ with or without allicin treatment at 10,30 or $100 \mu \mathrm{g} / \mathrm{ml}$ for $24 \mathrm{~h}$ at $37^{\circ} \mathrm{C}$. Next, MTT solution was added to each well and the plates were incubated for an additional $2 \mathrm{~h}$ at $37^{\circ} \mathrm{C}$. Subsequent to the removal of the solutions from the well, dimethyl sulfoxide (Thermo Fisher Scientific, Inc.) was added to dissolve formazan products. Finally, the absorbance of each well was recorded on a microplate spectrophotometer (PowerWave XS2; BioTek Instruments, Inc., Winooski, VT, USA) at $570 \mathrm{~nm}$.

Apoptosis of MC3T3-E1 cells subsequent to treatment was examined with an Annexin V-FITC Apoptosis Detection kit (Sigma-Aldrich). In brief, $5 \times 10^{5}$ cells were collected subsequent to treatments and were stained with annexin V-FITC and propidium iodide at $25^{\circ} \mathrm{C}$ for $5-15 \mathrm{~min}$ (placed in the dark). Apoptotic cells were then detected using a flow cytometer (BRYTE HS; Bio-Rad Laboratories, Inc., Hercules, CA, USA) and were quantified by calculating the percentage of apoptotic cells relative to the total number of cells using FlowJo 7.6 (Tree Star, Inc., Ashland, OR, USA).
Protein sample isolation and western blot analysis. Following treatment with $200 \mu \mathrm{M} \mathrm{H}_{2} \mathrm{O}_{2}$ for $6 \mathrm{~h}$ with or without 10,30 or $100 \mu \mathrm{g} / \mathrm{ml}$ allicin for $24 \mathrm{~h}$, MC3T3-E1 cells were collected and lyzed with an ice-cold cell lysis reagent (FNN0091; Thermo Fisher Scientific, Inc.) according to the manufacturer's instructions, and were then supplemented with protease inhibitors (04693116001; Roche Diagnostics, $\mathrm{GmbH}$, Mannheim, Germany). The protein concentration of each sample was measured using the Pierce bicinchoninic acid assay reagent (Thermo Fisher Scientific, Inc., Rockford, IL, USA). Samples were separated using 8-12\% SDS-PAGE gel, with a sample volume of $25 \mu \mathrm{g}$ each, on a protein electrophoresis apparatus (Mini-PROTEAN Tetra Cell; Bio-Rad Laboratories, Inc.) at $80 \mathrm{~V}$ for $25 \mathrm{~min}$ and $120 \mathrm{~V}$ for $75 \mathrm{~min}$. Next, the separated proteins were transferred to a polyvinylidene difluoride membranes (EMD Millipore, Bedford, MA, USA) and were blocked with $2 \%$ bovine serum albumin (BioVision, Mountain View, CA, USA) at $4^{\circ} \mathrm{C}$ overnight. Membranes were inoculated with rabbit polyclonal antibody against caspase 3 (cat. no. 9662; 1:400; Cell Signaling Technology, Inc., Danvers, MA, USA) and poly adenosine diphosphate-ribose polymerase (PARP; cat. no. 5625, 1:800; Cell Signaling Technology, Inc.), cytochrome $c$ (ab90529, 1:600; Abcam, Cambridge, UK), Akt and caspase 9 (C7729, 1:300; Sigma-Aldrich), cAMP response element-binding protein (CREB) with (sc-101663; 1:600) or without S133 phosphorylation (sc-25785; 1:800), extracellular signal-regulated kinases (ERKs) with (sc-101761; 1:600) or without T204 phosphorylation (sc-292838; 1:800; Santa Cruz Biotechnology, Inc.) or to tubulin (13918-T16-100; 1:1,000; Sino Biological, Inc., Beijing, China) at $4^{\circ} \mathrm{C}$ overnight. A goat anti-rabbit IgG conjugated to horseradish peroxidase secondary antibody was used (A27036; 1:600; Thermo Fisher Scientific, Inc.) and a Novex ECL Chemiluminescent Substrate Reagent Kit (WP20005; Thermo Fisher Scientific, Inc.) was used to detect the specific binding of each target protein to its antibody. The results were expressed as relative protein levels to tubulin.

Determination of complex IV activity and mitochondrial membrane potential. Complex IV activity was measured with a Complex IV Rodent Enzyme Activity Microplate Assay kit (Abcam) according to the manufacturer's instructions. Briefly, MC3T3-E1 cell samples underwent detergent extraction with 1:10 volume detergent followed by $12,000 \mathrm{x}$ g centrifugation for $20 \mathrm{~min}$ to extract the supernatants. Supernatant samples were quantified to an optimal concentration of $5 \mathrm{mg} / \mathrm{ml}$, and were serially diluted using $1 \mathrm{X}$ phosphate-buffered saline. Samples were then loaded onto plates (100 $\mu 1$ per well), with a positive control sample and buffer control included as null reference. This step was performed to enable the binding of complex IV to the bound monoclonal antibody, included in the kit, which immobilized the enzyme in the wells. Following a 3 -h incubation at $25^{\circ} \mathrm{C}$, each well was rinsed twice with solution $1(100 \mu 1$ per well), then assay solution was added (100 $\mu 1$ per well). Finally, the reaction was measured for optical density at $550 \mathrm{~nm}$ absorbance at $1-5 \mathrm{~min}$ intervals for $2 \mathrm{~h}$ at $30^{\circ} \mathrm{C}$ using a spectrophotometer (PowerWave XS2). The results were expressed as a percentage of the complex IV activity of the control MC3T3-E1 cells. 
A tetramethylrhodamine, ethyl ester (TMRE) Mitochondrial Membrane Potential Assay kit (Abcam) was used according to the manufacturer's instructions. TMRE is a cell-permeant, positively-charged, red-orange dye that readily accumulates in active mitochondria due to their relative negative charge. Depolarized or inactive mitochondria have a decreased membrane potential and fail to sequester TMRE. A total of $1 \times 10^{5}$ MC3T3-E1 cells per treatment group were incubated with the mitochondrial membrane potential (MMP)-sensitive fluorescent TMRE for $20 \mathrm{~min}$ at $37^{\circ} \mathrm{C}, 5 \% \mathrm{CO}_{2}(1,000 \mathrm{nM}$ FCCP was added to the positive control cells $10 \mathrm{~min}$ prior to TMRE addition). Following incubation, the cells were trypsinized (0.25\%; Ameresco, Inc., Framingham, MA, USA), centrifuged and cell pellets were resuspended in $0.4 \mathrm{ml}$ of Dulbecco's phosphate-buffered saline (Sigma-Aldrich) with $0.2 \%$ bovine serum albumin (BioVision) and analyzed for TMRE fluorescence by flow cytometry using FlowJo 7.6, with an excitation/emission fluorescence for TMRE of 549/575 $\mathrm{nm}$.

Measurement of ROS and mitochondrial superoxide. The intracellular level of ROS was quantified by the oxidation of the ROS-sensitive fluorophore dichloro-dihydro-fluorescein diacetate (Thermo Fisher Scientific, Inc., Waltham, MA, USA) according to the manufacturer's instructions. In brief, confluent MC3T3-E1 cells in 6-well plates $\left(5 \times 10^{5}\right.$ cells/well) were loaded with a $5 \mu \mathrm{M}$ probe (5-chloromethyl-2,7-dichlorodihydrofluorescein diacetate) in Hanks' balanced salt solution (HBSS; Thermo Fisher Scientific, Inc.) and were incubated at $37^{\circ} \mathrm{C}$ and $5 \% \mathrm{CO}_{2}$ for $30 \mathrm{~min}$. The cells were rinsed with HBSS subsequent to the removal of the probe and the 2,7-dichlorofluorescein fluorescence was measured using a luminescence spectrometer (2390-0000; PerkinElmer, Inc., Waltham, MA, USA) with an excitation source at $488 \mathrm{~nm}$ and an emission at $530 \mathrm{~nm}$. The mitochondrial superoxide levels were detected using a Molecular Probes MitoSOX Red Mitochondrial Superoxide Indicator (Thermo Fisher Scientific, Inc.), which is a fluorogenic dye (excitation/emission $=510 / 580 \mathrm{~nm}$ ) for highly selective detection of superoxide in the mitochondria of cells. Subsequent to the different treatments, cells were incubated with $5 \mu \mathrm{M}$ MitoSOX Red at $37^{\circ} \mathrm{C}$ for $20 \mathrm{~min}$ and then the MitoSOX Red fluorescence was detected following removal and washing of the cells.

Measurement of phosphoinositide 3-kinase (PI3K) and Akt activities, and phosphorylated CREB. PI3K activity in lysates of MC3T3-E1 cells following the various treatments was evaluated using a PI3-Kinase Activity ELISA kit (Echelon Biosciences, Inc., Salt Lake City, UT, USA). The assay was a competitive ELISA in which the signal is inversely proportional to the amount of phosphatidylinositol $(3,4,5)$ trisphosphate $\left(\mathrm{PIP}_{3}\right)$ produced. Subsequent to the completion of the PI3K reactions, the reaction products were first mixed and incubated with a $\mathrm{PIP}_{3}$ antibody and then added to a $\mathrm{PIP}_{3}$-coated microplate for competitive binding. A peroxidase-linked secondary antibody and colorimetric detection were used to detect the $\mathrm{PIP}_{3}$ detector binding to the plate. The colorimetric signal is inversely proportional to the amount of $\mathrm{PIP}_{3}$ produced by PI3K.
Statistical analysis. All the experiments were conducted in triplicate and the results are expressed as the mean \pm standard error of at least three independent experiments. The statistical significance was determined by analysis of variance and subsequently applying Student's t-test. $\mathrm{P}<0.05$ was considered to indicate a statistically significant difference.

\section{Results}

Allicin inhibits the $\mathrm{H}_{2} \mathrm{O}_{2}$-promoted apoptosis in MC3T3-El osteoblast cells. In order to investigate the anti-OS effects of allicin in MC3T3-E1 cells, they were exposed to $\mathrm{H}_{2} \mathrm{O}_{2}$ to mimic ROS elevation, and the effects of the exposure on cell viability and apoptosis were evaluated. The MC3T3-E1 cells were treated with $200 \mu \mathrm{M} \mathrm{H}_{2} \mathrm{O}_{2}$ for $6 \mathrm{~h}$ and the cell viability was examined by MTT assay. The results indicated that the cell viability was significantly reduced by $\mathrm{H}_{2} \mathrm{O}_{2}$ treatment for $6 \mathrm{~h}$ ( $\mathrm{P}=0.00082$; Fig. 1A). Next, the apoptosis levels were examined by flow cytometry of the MC3T3-E1 cells following $200 \mu \mathrm{M}$ $\mathrm{H}_{2} \mathrm{O}_{2}$ treatment for $6 \mathrm{~h}$, and consistent with the cell viability results, Fig. 1B indicated that there was a significantly higher percentage of apoptotic cells in the $200 \mu \mathrm{M} \mathrm{H}_{2} \mathrm{O}_{2}$-treated group ( $\mathrm{P}=0.00034)$. The MC3T3-E1 cells were treated with $200 \mu \mathrm{M}$ $\mathrm{H}_{2} \mathrm{O}_{2}$ and with $0,10,30$ or $100 \mu \mathrm{g} / \mathrm{ml}$ allicin and then the cell viability and apoptosis levels were measured. Compared with the $\mathrm{H}_{2} \mathrm{O}_{2}$ treatment alone, the combined treatment of $\mathrm{H}_{2} \mathrm{O}_{2}$ with $10(\mathrm{P}=0.033), 30$ or $100 \mu \mathrm{g} / \mathrm{ml}(\mathrm{P}=0.00090)$ allicin significantly ameliorated the cell viability. This effect was increased in the $30 \mu \mathrm{g} / \mathrm{ml}$ group compared with the $10 \mu \mathrm{g} / \mathrm{ml}$ group ( $\mathrm{P}=0.042$; Fig. 1A). Furthermore, a combined treatment of $\mathrm{H}_{2} \mathrm{O}_{2}$ with allicin demonstrated that $\mathrm{H}_{2} \mathrm{O}_{2}$-induced apoptosis was significantly inhibited by the treatment of $10(\mathrm{P}=0.040), 30$ $\mathrm{P}=0.0076)$ or $100 \mu \mathrm{g} / \mathrm{ml}(\mathrm{P}=0.0065)$ allicin and the inhibition was significantly increased in the $30 \mu \mathrm{g} / \mathrm{ml}$ group compared with the $10 \mu \mathrm{g} / \mathrm{ml}$ group ( $\mathrm{P}=0.022$ ) (Fig. 1B).

In order to confirm the effect of allicin on $\mathrm{H}_{2} \mathrm{O}_{2}$-induced apoptosis in MC3T3-E1 cells, cytochrome $c$ release and caspase 3 activation (catalyzed from pro-caspase 3 into 17- and 12-kDa subunits) were measured in the $\mathrm{H}_{2} \mathrm{O}_{2}$-treated cells by western blot assay. It was demonstrated that the $200 \mu \mathrm{M} \mathrm{H}_{2} \mathrm{O}_{2}$ treatment for $6 \mathrm{~h}$ promoted increased levels of cytochrome $c$ release $\mathrm{P}=0.00041)$, activated caspase- 3 $(\mathrm{P}=0.00037)$ and lyzed PARP $(\mathrm{P}=0.00083)$ by activated caspase-3 (Fig. 1C-F). However, allicin treatment with 10, 30 and $100 \mu \mathrm{g} / \mathrm{ml}$ partially reversed the effect of $\mathrm{H}_{2} \mathrm{O}_{2}$ treatment and led to reduced cytochrome $c$ release $(\mathrm{P}=0.041$, $\mathrm{P}=0.0085$ and $\mathrm{P}=0.00047$, respectively; Fig. 1D), caspase 3 activation $(\mathrm{P}=0.040, \mathrm{P}=0.028$ and $\mathrm{P}=0.0066$, respectively; Fig. 1E) and PARP lysis $(\mathrm{P}>0.05, \mathrm{P}=0.0080$ and $\mathrm{P}=0.0043$, respectively; Fig. 1F). These effects were also observed to increase in a dose-dependent manner.

Allicin ameliorates mitochondrial dysfunction in $\mathrm{H}_{2} \mathrm{O}_{2}$-treated MC3T3-E1 cells. The influence of allicin on the $\mathrm{H}_{2} \mathrm{O}_{2}$-induced osteoblast mitochondrial dysfunction was also evaluated. ROS generation in MC3T3-E1 cells with or without the treatment of $200 \mu \mathrm{M} \mathrm{H}_{2} \mathrm{O}_{2}$ was assessed. A significantly elevated ROS release from $\mathrm{H}_{2} \mathrm{O}_{2}$-treated cells was indicated $(\mathrm{P}=0.00093$; Fig. 2A). However, this increase was blocked by $10(\mathrm{P}=0.038)$, $30(\mathrm{P}=0.0086)$ or $100 \mu \mathrm{g} / \mathrm{ml}(\mathrm{P}=0.0075)$ allicin, and the 

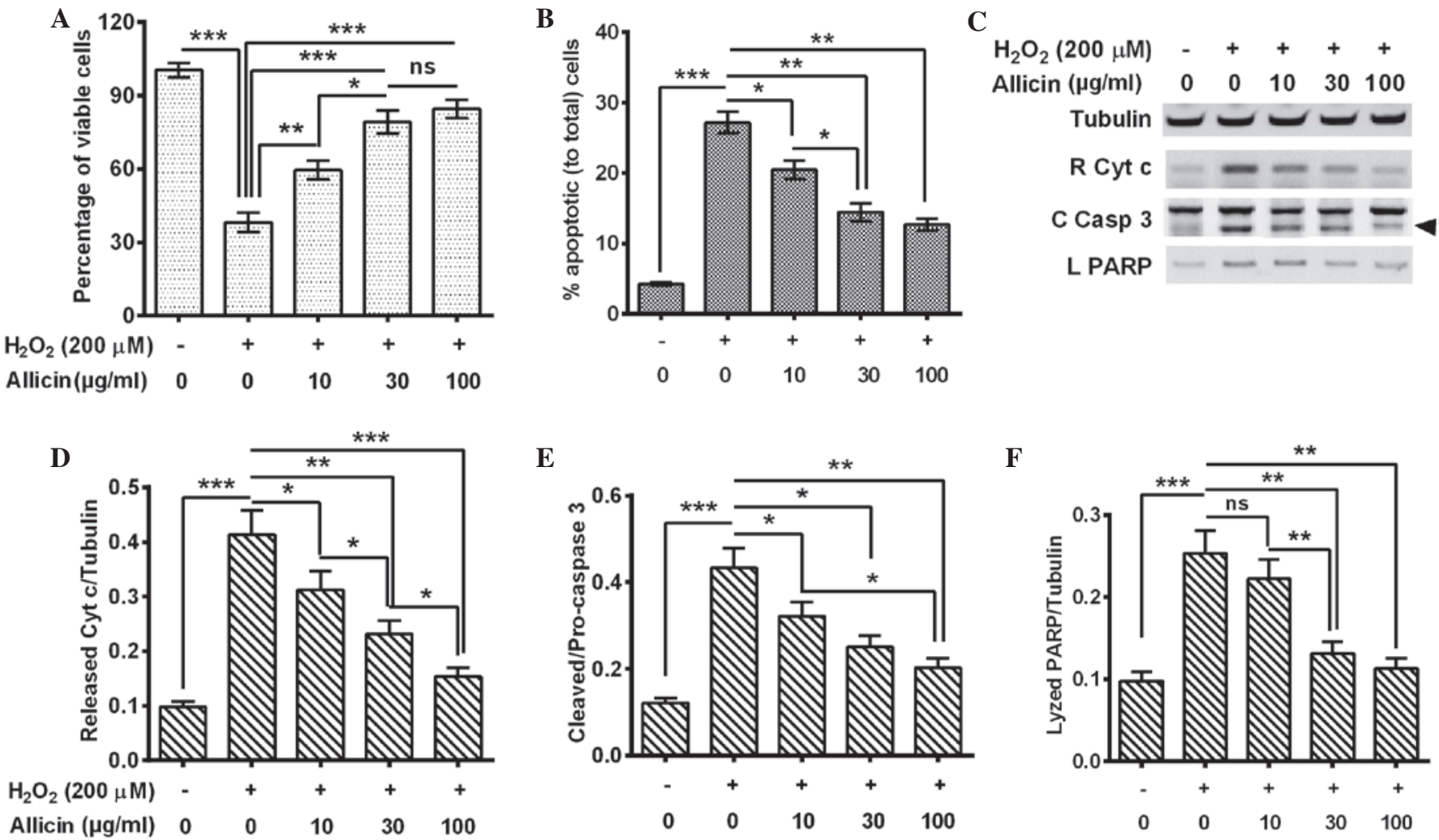

Figure 1. Allicin inhibited $\mathrm{H}_{2} \mathrm{O}_{2}$-induced apoptosis in mouse osteoblastic MC3T3-E1 cells. MC3T3-E1 cells were treated with $\mathrm{H}_{2} \mathrm{O}_{2}(200 \mu \mathrm{M})$ for $6 \mathrm{~h}$ and 10,30 or $100 \mu \mathrm{g} / \mathrm{ml}$ allicin for $24 \mathrm{~h}$. (A) Cell viabilities. (B) Percentages of apoptotic cells; apoptotic cells were examined with an annexin V-FITC apoptosis detection kit. (C) Western blot analysis of cytochrome $c$ release from mitochondria, cleaved caspase 3 (arrow) and lyzed PARP by caspase 3 . (D) Ratio of released cytochrome $c$ to tubulin. (E) Ratio of cleaved caspase 3 to pro-caspase 3. (F) Ratio of lyzed PARP to tubulin. All the experiments were performed in triplicate. ${ }^{*} \mathrm{P}<0.05,{ }^{* *} \mathrm{P}<0.01$ or ${ }^{* * * *} \mathrm{P}<0.001$, comparisons shown by brackets. ns, no significance; C Casp 3, cleaved caspase 3; L PARP, lyzed poly adenosine diphosphate-ribose polymerase; FITC, fluorescein isothiocyanate.

$30 \mu \mathrm{g} / \mathrm{ml}$ group was significantly reduced compared with the $10 \mu \mathrm{g} / \mathrm{ml}$ group $(\mathrm{P}=0.048)$. Secondly, mitochondrial superoxide was measured using MitoSOX Red, a live-cell-permeable and mitochondrial-localizing superoxide indicator that further assessed the effect of allicin on mitochondrial superoxide production. It was demonstrated that $\mathrm{H}_{2} \mathrm{O}_{2}$ treatment enhanced mitochondrial MitoSOX Red fluorescence ( $\mathrm{P}=0.00071$; Fig. 2B) whereas treatment with allicin with a concentration of $10(\mathrm{P}=0.0094), 30(\mathrm{P}=0.00087)$ and $100 \mu \mathrm{g} / \mathrm{ml}(\mathrm{P}=0.00092)$ substantially inhibited the stimulatory effect of $\mathrm{H}_{2} \mathrm{O}_{2}$ to the mitochondrial superoxide production (Fig. 2B).

In addition, the activity of the mitochondrial respiratory chain complex IV and mitochondrial membrane potential was examined. The complex IV activity decreased dramatically in the $\mathrm{H}_{2} \mathrm{O}_{2}$-treated cells ( $\mathrm{P}=0.0032$; Fig. 2C). However, allicin significantly ameliorated this effect $(10 \mu \mathrm{g} / \mathrm{ml}$, $\mathrm{P}=0.044 ; 30 \mu \mathrm{g} / \mathrm{ml}, \mathrm{P}=0.0063$; or $100 \mu \mathrm{g} / \mathrm{ml}, \mathrm{P}=0.0053$; Fig. $2 \mathrm{C}$ ) and the activity was significantly higher in the $30 \mu \mathrm{g} / \mathrm{ml}$ group compared with the $10 \mu \mathrm{g} / \mathrm{ml}$ group $(\mathrm{P}=0.028$; Fig. 2C). MMP, as a marker of mitochondrial oxidative phosphorylation activity, is a well-established indicator of mitochondrial function. As TMRE is a cell-permeable, positively-charged, red-orange dye that readily accumulates in active mitochondria due to their relative negative charge, the mitochondrial function was assessed by examining the TMRE accumulation in mitochondria. TMRE accumulation was significantly reduced by the $\mathrm{H}_{2} \mathrm{O}_{2}$ treatment $(\mathrm{P}=0.0037)$, and it was reversed by 10,30 or $100 \mu \mathrm{g} / \mathrm{ml}$ allicin (Fig. 2D). In conclusion, the results of the present study confirmed that allicin may protect from mitochondrial damage in MC3T3-E1 cells following OS.

Allicin ameliorates the reduction of PI3K/AKT activity in osteoblasts by $\mathrm{H}_{2} \mathrm{O}_{2}$. The PI3K/AKT pathway is important in cell survival, particularly against OS $(29,30)$. To further deduce the mechanism of the cytoprotective effect of allicin, the present study investigated whether PI3K/AKT activation was implicated in the cytoprotective effect of allicin in osteoblastic MC3T3-E1 cells. It was demonstrated that PI3K activity was significantly decreased in the MC3T3-E1 cells subsequent to $\mathrm{H}_{2} \mathrm{O}_{2}$ treatment $(\mathrm{P}=0.0036$; Fig. 3A). The treatment with $30(\mathrm{P}=0.024)$ or $100 \mu \mathrm{g} / \mathrm{ml}(\mathrm{P}=0.0035)$ allicin markedly ameliorated this effect (Fig. 3A). Furthermore, western blotting indicated that phosphorylated (p)-AKT was also significantly downregulated $(\mathrm{P}=0.00037)$, whereas the cleaved caspase 9 (C Casp 9) was markedly promoted ( $\mathrm{P}=0.00040$ ) by $\mathrm{H}_{2} \mathrm{O}_{2}$ treatment (Fig. 3B-D). Notably, 30 and $100 \mu \mathrm{g} / \mathrm{ml}$ allicin significantly increased the level of p-AKT $(\mathrm{P}=0.0057$ and $\mathrm{P}=0.00048$, respectively; Fig. $3 \mathrm{C})$ and reduced levels of $\mathrm{C}$ casp $9(\mathrm{P}=0.0063$ and 0.00056 , respectively; Fig. $3 \mathrm{C}$ ) compared with the $\mathrm{H}_{2} \mathrm{O}_{2}$-only group. In summary, allicin was suggested to ameliorate the $\mathrm{H}_{2} \mathrm{O}_{2}$-induced PI3K/AKT pro-survival signal inhibition in osteoblasts by $\mathrm{H}_{2} \mathrm{O}_{2}$. 
A

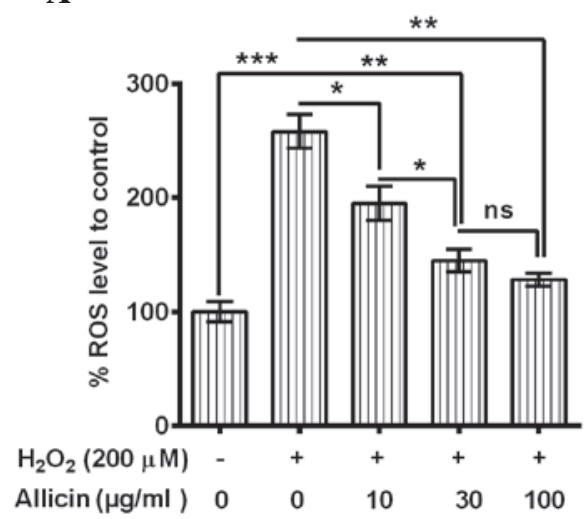

C

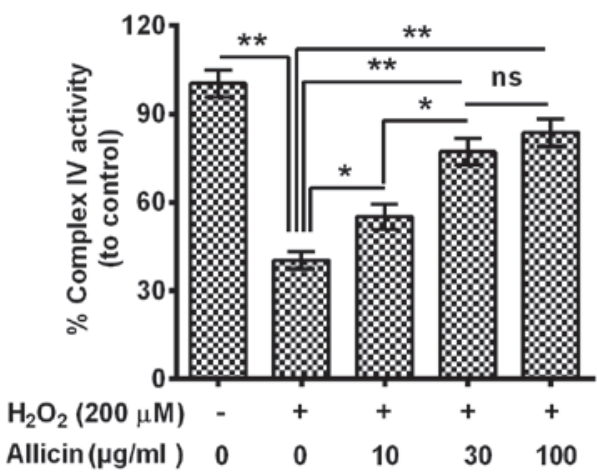

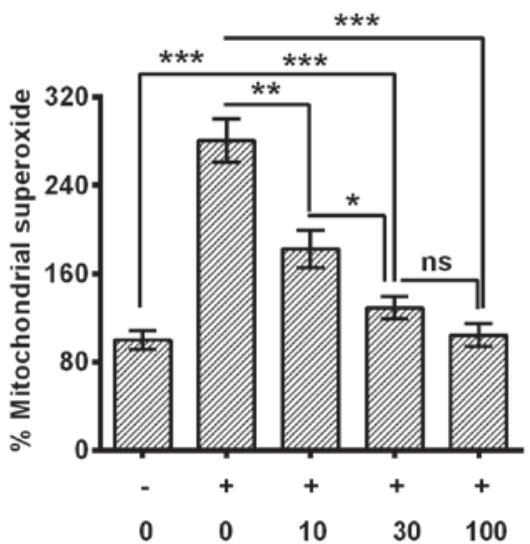

D

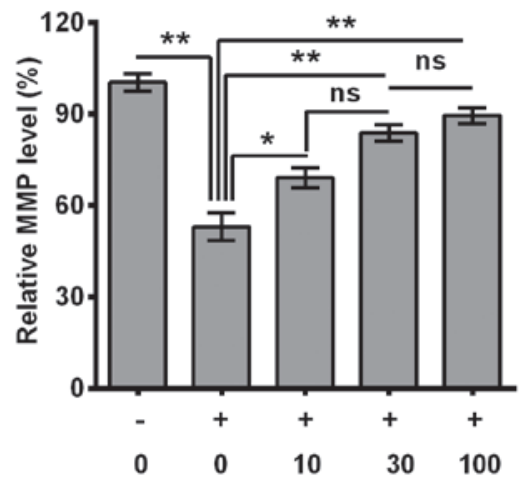

Figure 2. Effect of allicin on $\mathrm{H}_{2} \mathrm{O}_{2}$-induced mitochondrial dysfunction in osteoblastic MC3T3-E1 cells. Osteoblasts were incubated with 10, 30 or 100 $\mu \mathrm{g} / \mathrm{ml}$ allicin for $24 \mathrm{~h}$ and $\mathrm{H}_{2} \mathrm{O}_{2}$ treatment for $6 \mathrm{~h}$. (A) Average levels of ROS, which were measured by a dichloro-dihydro-fluorescein diacetate fluorescence method. (B) Mitochondrial superoxide levels detected using MitoSOX Red mitochondrial superoxide indicator. (C) Complex IV activity. (D) MMP measured by TMRE fluorescence. Results are the average of three independent experiments. ${ }^{*} \mathrm{P}<0.05,{ }^{* * *} \mathrm{P}<0.01$ or ${ }^{* * * *} \mathrm{P}<0.001$, comparison shown by brackets. ns, no significance; ROS, reactive oxygen species; MMP, mitochondrial membrane potential.

Allicin ameliorates the reduction of CREB/ERK signaling in osteoblasts by $\mathrm{H}_{2} \mathrm{O}_{2}$. CREB/ERK signaling was also demonstrated to be involved in OS (31). In the present study, the activation of CREB/ERK signaling was also demonstrated, and p-CREB and p-ERK levels were altered in the MC3T3-E1 cells following the treatment with $\mathrm{H}_{2} \mathrm{O}_{2}$ and allicin. The $\mathrm{H}_{2} \mathrm{O}_{2}$ treatment significantly reduced the level of $\mathrm{p}-\mathrm{CREB}(\mathrm{P}=0.00071)$ and p-ERK ( $\mathrm{P}=0.00033)$ in the MC3T3-E1 cells (Fig. 4). Allicin treatment with 10,30 or $100 \mu \mathrm{g} / \mathrm{ml}$ markedly increased p-CREB $(\mathrm{P}=0.028, \mathrm{P}=0.015$ and $\mathrm{P}=0.0022$, respectively; Fig. $4 \mathrm{~B})$ and $\mathrm{p}$-ERK $(\mathrm{P}=0.036, \mathrm{P}=0.0035$ and $\mathrm{P}=0.00045$, respectively; Fig. 4C) levels in MC3T3-E1 cells compared with the $\mathrm{H}_{2} \mathrm{O}_{2}$-only group. In summary, it was suggested that allicin ameliorates the $\mathrm{H}_{2} \mathrm{O}_{2}$-induced CREB/ERK pro-survival signaling inhibition in osteoblasts via $\mathrm{H}_{2} \mathrm{O}_{2}$.

\section{Discussion}

Mitochondria are the key targets for ROS, which have been suggested to regulate the processes involved in mitochondrial dysfunction and the promotion of apoptosis. Increased generation of ROS induces cytochrome $c$ release from mitochondria (21). In a previous study, the mimicking of ROS elevation by exposure to $\mathrm{H}_{2} \mathrm{O}_{2}$ resulted in the release of cytochrome $c$, which promoted apoptosis (22). ROS has also been demonstrated to cause structural and functional damage to mitochondria (32). The elevated ROS production causes mitochondrial damage, such as collapse of the mitochondrial membrane potential and complex IV inactivation, which opens up the mitochondrial permeability transition pores and leads to the release of proapoptotic proteins into the cytoplasm $(33,34)$.

In the present study, allicin was indicated to ameliorate the viability of cells by decreasing and inhibiting apoptosis in MC3T3-E1 cells. In the present study, apoptosis was induced by manipulating ROS elevation through exposure of MC3T3-E1 cells to $\mathrm{H}_{2} \mathrm{O}_{2}$. The inhibitory effect of allicin was confirmed by the inhibition of the $\mathrm{H}_{2} \mathrm{O}_{2}$-induced cytochrome $c$ release and the activation of caspase-3 after treatment. Additionally, apoptosis inhibition was hypothesized to be associated with the counteraction to $\mathrm{H}_{2} \mathrm{O}_{2}$-induced mitochondrial dysfunction. Allicin treatment inhibited the $\mathrm{H}_{2} \mathrm{O}_{2}$-induced ROS generation and mitochondrial superoxide activation, whereas it ameliorated the $\mathrm{H}_{2} \mathrm{O}_{2}$-induced reduction of complex IV activity and mitochondrial membrane potential. Furthermore, the counteraction of $\mathrm{H}_{2} \mathrm{O}_{2}$-induced mitochondrial dysfunction was also verified by the inhibition to $\mathrm{H}_{2} \mathrm{O}_{2}$-induced nitrotyrosine production and the amelioration of the $\mathrm{H}_{2} \mathrm{O}_{2}$-induced thioredoxin reductase activity decreasing. In addition, allicin improved the pro-survival signal inhibition in osteoblasts via $\mathrm{H}_{2} \mathrm{O}_{2}$. However, it remains unclear how allicin reduces the $\mathrm{H}_{2} \mathrm{O}_{2}$-induced ROS generation. It is considered that the protective effect of allicin on $\mathrm{H} 9 \mathrm{c} 2$ cells may inhibit intracellular ROS production (35). Therefore, the present study speculated 
A

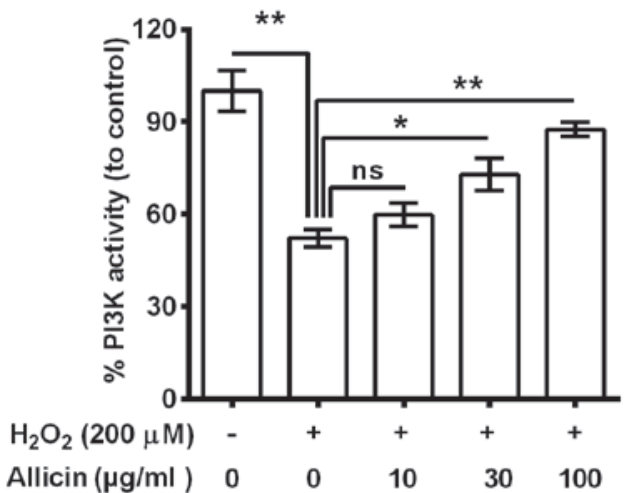

B

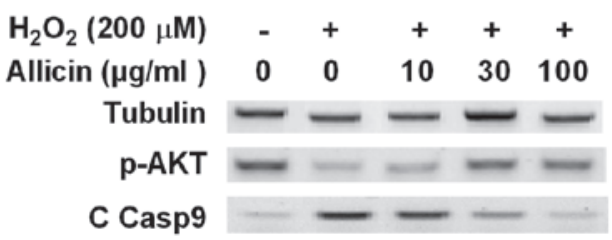

C

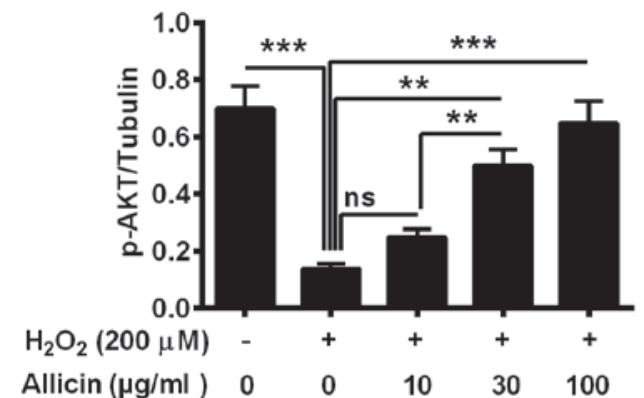

D

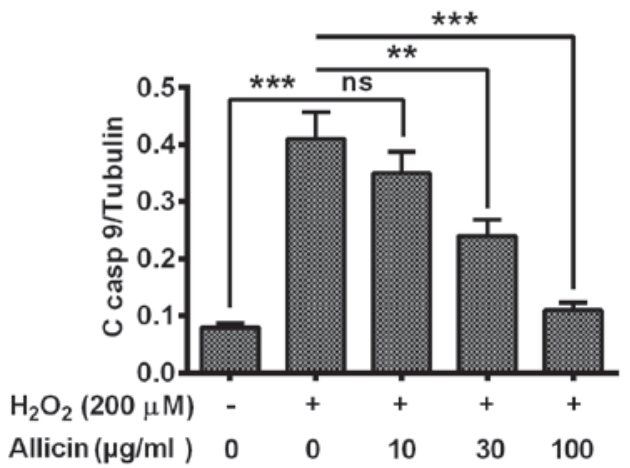

Figure 3. Effect of allicin on the activity of PI3K/AKT in MC3T3-E1 cells treated with $\mathrm{H}_{2} \mathrm{O}_{2}(200 \mu \mathrm{M})$ for $6 \mathrm{~h}$ and 10,30 or $100 \mu \mathrm{g} / \mathrm{ml}$ allicin for $24 \mathrm{~h}$. (A) PI3K levels assessed using ELISA assay. (B) Western blotting of p-AKT and cleaved caspase 9. Quantification of western blots of (C) p-AKT and (D) $\mathrm{C}$ casp 9 were presented relative to tubulin. All of the experiments were performed in triplicate. ${ }^{*} \mathrm{P}<0.05,{ }^{* *} \mathrm{P}<0.01$ or ${ }^{* * *} \mathrm{P}<0.001$, comparisons shown by brackets. ns, no significance; PI3K, phosphoinositide 3-kinase; p-AKT, phosphorylated AKT; C casp 9, cleaved caspase 9.

that the inhibition of ROS production may be a key mechanism underlying the reduction of $\mathrm{H}_{2} \mathrm{O}_{2}$ toxicity by allicin. $\mathrm{PI} 3 \mathrm{~K}$ and CREB are established to function as pro-survival signals (36-40). In the present study, PI3K activity and CREB phosphorylation were reduced in MC3T3-E1 cells after $\mathrm{H}_{2} \mathrm{O}_{2}$ treatment, whereas allicin treatment prevented the reduction of PI3K activity and CREB phosphorylation.
A

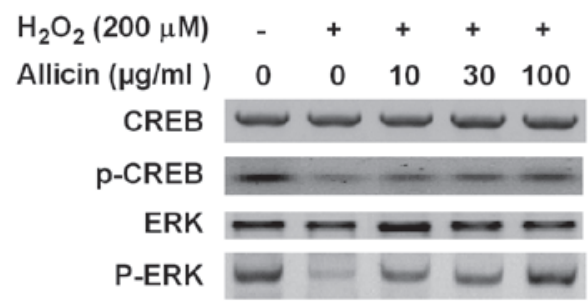

B

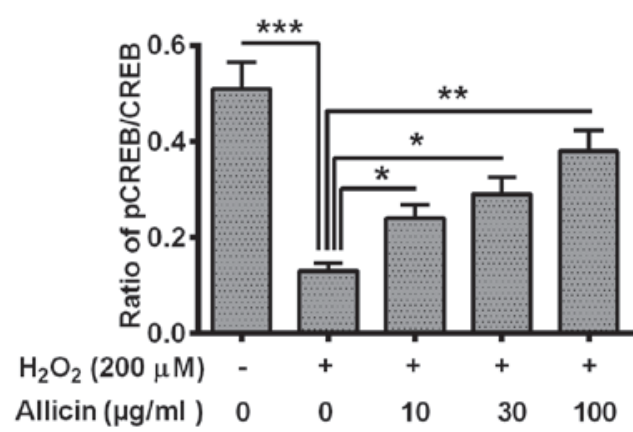

C

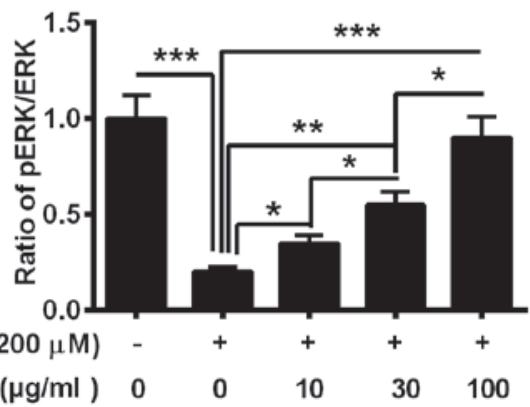

Figure 4. Effect of allicin on CREB/ERK phosphorylation of MC3T3-E1 cells treated with $\mathrm{H}_{2} \mathrm{O}_{2}(200 \mu \mathrm{M})$ for $6 \mathrm{~h}$ and 10,30 or $100 \mu \mathrm{g} / \mathrm{ml}$ allicin for $24 \mathrm{~h}$. (A) Western blotting of p-CREB (S133) and p-ERK (T202, T204). Relative levels of (B) p-CREB to total CREB or (C) p-ERK to total ERK. Results are presented as the averages of three independent experiments. ${ }^{*} \mathrm{P}<0.05,{ }^{* *} \mathrm{P}<0.01$ or ${ }^{* * * *} \mathrm{P}<0.001$, comparisons shown by brackets. CREB cAMP response element-binding protein; ERK, extracellular signal-regulated kinase; p-CREB, phosphorylated CREB; p-ERK, phosphorylated ERK.

OS has been indicated to be involved in the pathogenesis of osteoporosis. It is conceivable that mitochondrial-mediated ROS generation under OS leads to damage to ROS-produced cells or peripheral osteoblasts. As major sources of ROS production, mitochondria also are major targets for ROS. The present study demonstrated that mimicking OS by $\mathrm{H}_{2} \mathrm{O}_{2}$ exposure significantly exerted mitochondrial dysfunction in osteoblastic MC3T3-E1 cells. The anti-OS effect exerted by allicin has been previously identified in ischemic/reperfused rats by inhibiting the activation of c-Jun and c-Jun $\mathrm{N}$-terminal kinase, and thus inhibiting apoptosis further (41). However, the present study indicated that allicin inhibited ROS generation and ameliorated ROS-induced mitochondrial disfunction. In addition, the allicin treatment also ameliorated the repressed PI3K/AKT and CREB/ERK signaling by $\mathrm{H}_{2} \mathrm{O}_{2}$ that may also be associated with the anti-OS effect of allicin. Previously, PI3K and CREB were demonstrated to be involved in osteoblast-like cell proliferation and differentiation $(42,43)$. In the present study, allicin treatment on MC3T3-E1 cells led to increased PI3K activity, phosphorylation of AKT, CREB and ERK. PI3K is a lipid kinase and generates $\mathrm{PIP}_{3}$, which 
directly or indirectly affects CREB phosphorylation (44). CREB is a ubiquitous transcription factor in the higher eukaryotes that, once phosphorylated, promotes the synthesis of mitochondrially encoded subunits of oxidative phosphorylation complexes (45). By contrast, since the PI3K/AKT and CREB/ERK signaling pathways were suppressed by $\mathrm{H}_{2} \mathrm{O}_{2}$, the attenuation of the repressed PI3K and CREB by allicin may be caused by reduced $\mathrm{H}_{2} \mathrm{O}_{2}$ toxicity. In addition, the attenuation of the repressed PI3K and CREB may ameliorate the mitochondrial function via regulating the expression of B-cell lymphoma-2 and Bcl-extra large (46), which are located in the outer membrane of the mitochondria and regulate mitochondrial function (47).

Toconclude, allicin protectsosteoblasts from $\mathrm{H}_{2} \mathrm{O}_{2}$-induced OS and apoptosis in osteoblastic MC3T3-E1 cells by improving mitochondrial function and by activation of the PI3K/AKT and CREB/ERK signaling pathways. The present study implies a promising role for allicin in OS-associated osteoporosis.

\section{References}

1. Graat-Verboom L, Wouters EF, Smeenk FW, van den Borne BE, Lunde R and Spruit MA: Current status of research on osteoporosis in COPD: A systematic review. Eur Respir J 34: 209-218, 2009.

2. Zhao Y, Liu Y and Zheng Y: Osteoporosis and related factors in older females with skeletal pain or numbness: A retrospective study in East China. J Int Med Res 41: 859-866, 2013.

3. Abe E, Sun L, Mechanick J, Iqbal J, Yamoah K, Baliram R, Arabi A, Moonga BS, Davies TF and Zaidi M: Bone loss in thyroid disease: Role of low TSH and high thyroid hormone. Ann NY Acad Sci 1116: 383-391, 2007.

4. Compston JE: Risk factors for osteoporosis. Clin Endocrinol (Oxf) 36: 223-224, 1992.

5. Chrischilles EA, Butler CD, Davis CS and Wallace RB: A model of lifetime osteoporosis impact. Arch Intern Med 151: 2026-2032, 1991.

6. Shah M, Kola B, Bataveljic A, Arnett TR, Viollet B, Saxon L, Korbonits $\mathrm{M}$ and Chenu C: AMP-activated protein kinase (AMPK) activation regulates in vitro bone formation and bone mass. Bone 47: 309-319, 2010.

7. Lee NK, Sowa H, Hinoi E, Ferron M, Ahn JD, Confavreux C, Dacquin R, Mee PJ, McKee MD, Jung DY, et al: Endocrine regulation of energy metabolism by the skeleton. Cell 130: 456-469, 2007.

8. Pei L and Tontonoz P: Fat's loss is bone's gain. J Clin Invest 113: 805-806, 2004.

9. Rosen CJ and Bouxsein ML: Mechanisms of disease: Is osteoporosis the obesity of bone? Nat Clin Pract Rheumatol 2: 35-43, 2006.

10. Slemmer JE, Shacka JJ, Sweeney MI and Weber JT: Antioxidants and free radical scavengers for the treatment of stroke, traumatic brain injury and aging. Curr Med Chem 15: 404-414, 2008.

11. Lopes JP, Oliveira SM and Soares FJ: Oxidative stress and its effects on insulin resistance and pancreatic beta-cells dysfunction: Relationship with type 2 diabetes mellitus complications. Acta Med Port 21: 293-302, 2008 (In Portuguese).

12. Kingwell BA: Nitric oxide-mediated metabolic regulation during exercise: Effects of training in health and cardiovascular disease. Faseb J 14: 1685-1696, 2000.

13. Maharjan BR, Jha JC, Adhikari D, Akila, Risal S, Alurkar VM and Singh PP: Oxidative stress, antioxidant status and lipid profile in ischemic heart disease patients from western region of Nepal. Nepal Med Coll J 10: 20-24, 2008.

14. Sendur OF, Turan Y, Tastaban E and Serter M: Antioxidant status in patients with osteoporosis: A controlled study. Joint Bone Spine 76: 514-518, 2009.

15. Sánchez-Rodríguez MA, Ruiz-Ramos M, Correa-Muñoz E and Mendoza-Núñez VM: Oxidative stress as a risk factor for osteoporosis in elderly Mexicans as characterized by antioxidant enzymes. BMC Musculoskelet Disord 8: 124, 2007.

16. Ozgocmen S, Kaya H, Fadillioglu E, Aydogan R and Yilmaz Z: Role of antioxidant systems, lipid peroxidation, and nitric oxide in postmenopausal osteoporosis. Mol Cell Biochem 295: 45-52, 2007.
17. Basu S, Michaëlsson K, Olofsson H, Johansson S and Melhus H: Association between oxidative stress and bone mineral density. Biochem Biophys Res Commun 288: 275-279, 2001.

18. Steinberg GR and Kemp BE: AMPK in Health and Disease. Physiol Rev 89: 1025-1078, 2009.

19. Morgan MJ and Liu ZG: Reactive oxygen species in TNFalpha-induced signaling and cell death. Mol Cells 30: 1-12, 2010.

20. Freitas I, Griffini P, Bertone V, Bertone R, Fenoglio C, Milliery $\mathrm{R}$ and Vairetti $\mathrm{M}$ : In situ detection of reactive oxygen species and nitric oxide production in normal and pathological tissues: Improvement by differential interference contrast. Exp Gerontol 37: 591-602, 2002.

21. Tan S, Sagara Y, Liu Y, Maher P and Schubert D: The regulation of reactive oxygen species production during programmed cell death. J Cell Biol 141: 1423-1432, 1998

22. Kirkland RA, Windelborn JA, Kasprzak JM and Franklin JL: A Bax-induced pro-oxidant state is critical for cytochrome c release during programmed neuronal death. J Neurosci 22: 6480-6490, 2002.

23. Zhang Z, Zheng L, Zhao Z, Shi J, Wang X and Huang J: Grape seed proanthocyanidins inhibit $\mathrm{H}_{2} \mathrm{O}_{2}$-induced osteoblastic MC3T3-E1 cell apoptosis via ameliorating H2O2-induced mitochondrial dysfunction. J Toxicol Sci 39: 803-813, 2014.

24. Chan SW: Panax ginseng, Rhodiola rosea and Schisandrachinensis. Int J Food Sci Nutr 63 (Suppl 1): S75-S81, 2012.

25. Borlinghaus J, Albrecht F, Gruhlke MC, Nwachukwu ID and Slusarenko AJ: Allicin: Chemistry and biological properties. Molecules 19: 12591-12618, 2014.

26. Kita T, Kume N, Minami M, Hayashida K, Murayama T, Sano H, Moriwaki H, Kataoka H, Nishi E, Horiuchi $\mathrm{H}$, et al: Role of oxidized LDL in atherosclerosis. Ann NY Acad Sci 947: 199-206, 2001.

27. Arzanlou M, Bohlooli S, Jannati E and Mirzanejad-Asl H: Allicin from garlic neutralizes the hemolytic activity of intraand extra-cellular pneumolysin $\mathrm{O}$ in vitro. Toxicon 57: 540-545, 2011.

28. Mozaffari-Khosravi H, Hesabgar HA, Owlia MB, Hadinedoushan H, Barzegar K and Fllahzadeh MH: The effect of garlic tablet on pro-inflammatory cytokines in postmenopausal osteoporotic women: A randomized controlled clinical trial. J Diet Suppl 9: 262-271, 2012.

29. Padiya R, Chowdhury D, Borkar R, Srinivas R, Pal Bhadra M and Banerjee SK: Garlic attenuates cardiac oxidative stress via activation of PI3K/AKT/Nrf2-Keap1 pathway in fructose-fed diabetic rat. PLoS One 9: e94228, 2014.

30. Umoh NA, Walker RK, Al-Rubaiee M, Jeffress MA and Haddad GE: Acute alcohol modulates cardiac function as PI3K/Akt regulates oxidative stress. Alcohol Clin Exp Res 38: 1847-1864, 2014.

31. Zhang L and Jope RS: Oxidative stress differentially modulates phosphorylation of ERK, p38 and CREB induced by NGF or EGF in PC12 cells. Neurobiol Aging 20: 271-278, 1999.

32. Chomyn A and Attardi G: MtDNA mutations in aging and apoptosis. Biochem Biophys Res Commun 304: 519-529, 2003.

33. Balaban RS, Nemoto $S$ and Finkel T: Mitochondria, oxidants and aging. Cell 120: 483-495, 2005.

34. Choi EM: Magnolol protects osteoblastic MC3T3-E1 cells against antimycin A-induced cytotoxicity through activation of mitochondrial function. Inflammation 35: 1204-1212, 2012.

35. Chan JY, Tsui HT, Chung IY, Chan RY, Kwan YW and Chan SW: Allicin protects rat cardiomyoblasts ( $\mathrm{H} 9 \mathrm{c} 2$ cells) from hydrogen peroxide-induced oxidative injury through inhibiting the generation of intracellular reactive oxygen species. Int J Food Sci Nutr 65: 868-873, 2014.

36. Saavedra A, García-Martínez JM, Xifró X, Giralt A, Torres-Peraza JF, Canals JM, Díaz-Hernández M, Lucas JJ, Alberch J and Pérez-Navarro E: PH domain leucine-rich repeat protein phosphatase 1 contributes to maintain the activation of the PI3K/Akt pro-survival pathway in Huntington's disease striatum. Cell Death Differ 17: 324-335, 2010.

37. Bhattacharya D, Singh MK, Chaudhuri S, Acharya S, Basu AK and Chaudhuri S: T11TS impedes glioma angiogenesis by inhibiting VEGF signaling and pro-survival PI3K/Akt/eNOS pathway with concomitant upregulation of PTEN in brain endothelial cells. J Neurooncol 113: 13-25, 2013.

38. Hsu HH, Cheng LH, Ho TJ, Kuo WW, Lin YM, Chen MC, Lee NH, Tsai FJ, Tsai KH and Huang CY: Apicidin-resistant HA22T hepatocellular carcinoma cells massively promote pro-survival capability via IGF-IR/PI3K/Akt signaling pathway activation. Tumour Biol 35: 303-313, 2014. 
39. Das S, Tosaki A, Bagchi D, Maulik N and Das DK: Potentiation of a survival signal in the ischemic heart by resveratrol through $\mathrm{p} 38$ mitogen-activated protein kinase/mitogen- and stress-activated protein kinase 1/cAMP response element-binding protein signaling. J Pharmacol Exp Ther 317: 980-988, 2006.

40. Dworkin S, Malaterre J, Hollande F, Darcy PK, Ramsay RG and Mantamadiotis T: cAMP response element binding protein is required for mouse neural progenitor cell survival and expansion. Stem Cells 27: 1347-1357, 2009.

41. Sato M, Bagchi D, Tosaki A and Das DK: Grape seed proanthocyanidin reduces cardiomyocyte apoptosis by inhibiting ischemia/reperfusion-induced activation of JNK-1 and C-JUN. Free Radic Biol Med 31: 729-737, 2001.

42. Carpio L, Gladu J, Goltzman D and Rabbani SA: Induction of osteoblast differentiation indexes by PTHrP in MG-63 cells involves multiple signaling pathways. Am J Physiol Endocrinol Metab 281: E489-E499, 2001.
43. Matsuo N, Tanaka S, Gordon MK, Koch M, Yoshioka H and Ramirez F: CREB-AP1 protein complexes regulate transcription of the collagen XXIV gene (Col24a1) in osteoblasts. J Biol Chem 281: 5445-5452, 2006

44. Vivanco I and Sawyers CL: The phosphatidylinositol 3-kinase AKT pathway in human cancer. Nat Rev Cancer 2: 489-501, 2002.

45. De Rasmo D, Signorile A, Roca E and Papa S: cAMP response element-binding protein (CREB) is imported into mitochondria and promotes protein synthesis. FEBS J 276: 4325-4333, 2009.

46. Boucher MJ, Morisset J, Vachon PH, Reed JC, Lainé J and Rivard N: MEK/ERK signaling pathway regulates the expression of $\mathrm{Bcl}-2, \mathrm{Bcl}-\mathrm{X}(\mathrm{L})$ and $\mathrm{Mcl}-1$ and promotes survival of human pancreatic cancer cells. J Cell Biochem 79: 355-369, 2000.

47. Chan SL and Yu VC: Proteins of the bcl-2 family in apoptosis signalling: From mechanistic insights to therapeutic opportunities. Clin Exp Pharmacol Physiol 31: 119-128, 2004. 